\title{
Temozolomide in Advanced Neuroendocrine Neoplasms: Pharmacological and Clinical Aspects
}

\author{
Anna Koumarianou $^{a}$ Gregory Kaltsas $^{b}$ Matthew H. Kulke ${ }^{c}$ Kjell Oberg ${ }^{e}$ \\ Jonathan R. Strosberg ${ }^{d}$ Francesca Spada $^{f}$ Salvatore Galdy ${ }^{f}$ \\ Massimo Barberis ${ }^{g}$ Caterina Fumagalli ${ }^{9}$ Alfredo Berruti ${ }^{\text {h }}$ Nicola Fazio ${ }^{f}$ \\ ${ }^{a}$ Hematology-Oncology Unit, Fourth Department of Internal Medicine, Attikon University Hospital, and \\ ${ }^{b}$ Endocrine Unit, Department of Pathophysiology, National University of Athens, Athens, Greece; ${ }^{c}$ Department \\ of Medical Oncology, Dana-Farber Cancer Institute, Boston, Mass., and d Lee Moffitt Cancer Center and Research

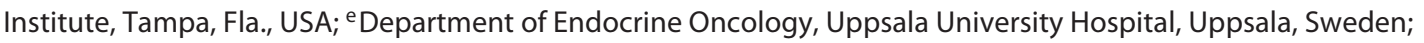 \\ ${ }_{\mathrm{f}}^{\mathrm{G}}$ astrointestinal Medical Oncology and Neuroendocrine Tumor Unit, and ${ }^{9}$ Division of Pathology, European \\ Institute of Oncology, Milan, and h Oncologia Medica, Dipartimento di Specialità Medico-Chirurgiche, Scienze \\ Radiologiche e Sanità Pubblica, Azienda Ospedaliera Spedali Civili, Università degli Studi di Brescia, Brescia, Italy
}

\section{Key Words}

Neuroendocrine neoplasms $\cdot$ Pancreatic neuroendocrine neoplasms · Neuroendocrine carcinomas $\cdot$ Ki-67 labelling index $\cdot$ Progression-free survival

\begin{abstract}
Alkylating agents, such as streptozocin and dacarbazine, have been reported as active in neuroendocrine neoplasms (NENs). Temozolomide (TMZ) is an oral, potentially less toxic derivative of dacarbazine, which has shown activity both as a single agent and in combination with other drugs. Nevertheless, its role in NENs has not been well defined. Several retrospective and prospective phase I-II studies have been published describing its use in a variety of NENs. In a retrospective series, the combination of capecitabine and TMZ was reported to be associated with a particularly high tumour response in pancreatic NENs as a first-line treatment. Although in NENs, determination of the $\mathrm{O}^{6}$-methylguanineDNA methyltransferase (MGMT) status has been suggested
\end{abstract}

\section{KARGER 125}

(c) 2015 S. Karger AG, Base

$0028-3835 / 15 / 1014-0274 \$ 39.50 / 0$

E-Mail karger@karger.com

www.karger.com/nen as a predictive biomarker of response, its role still remains investigational, awaiting validation along with the establishment of the optimal detection method. Metronomic schedules have been reported to potentially overcome MGMT-related drug resistance. Toxicity is manageable if well monitored. We reviewed the literature regarding pharmacological and clinical aspects of TMZ, focusing on specific settings of NENs, different schedules, toxicity and safety profiles, and potential predictive biomarkers of response.

(c) 2015 S. Karger AG, Basel

\section{Introduction}

Neuroendocrine neoplasms (NENs) constitute a relatively rare and heterogeneous group of tumours, arising from cells of the diffuse neuroendocrine system most

\section{Anna Koumarianou}

Hematology-Oncology Unit, Fourth Department of Internal Medicine Attikon University Hospital, Rimini 1

GR-12462 Athens (Greece)

E-Mail akoumari@yahoo.com

\section{Nicola Fazio}

Gastrointestinal Medical Oncology and Neuroendocrine Tumor Unit European Institute of Oncology

IT-20141 Milan (Italy)

E-Mail nicola.fazio@ieo.it 
commonly encountered in the gastrointestinal (GI) tract and the lung [1]. Neuroendocrine cells are characterized by amine and neuropeptide hormone production that, when biologically active, can lead to distinct clinical syndromes. Despite the diversity in tissue origin, the majority of tissues are well differentiated and have common features, including their growth pattern, expression of neuroendocrine markers, and response to treatment [2].

Since their initial description, the nomenclature and classification of NENs has evolved, hindering the collection of epidemiological information and comparison between published studies [3]. In 2010, a revised version of the WHO classification of gastroenteropancreatic NENs introduced specific term changes, including 'neuroendocrine' to indicate neoplastic cells expressing neural markers such as synaptophysin, and 'neuroendocrine neoplasm', which encompasses both well-differentiated and poorly differentiated neoplasms of neuroendocrine cells [4]. NENs were then separated further by their proliferative activity, based on the Ki-67 labelling index (LI) and/ or mitotic index that defined grading $(\mathrm{G})$, and differentiation [into well-differentiated neuroendocrine tumours (NETs; G1: Ki-67 LI <3\%; G2: Ki-67 LI 3-20\%) and poorly differentiated neuroendocrine carcinomas (NECs; G3: Ki-67 LI >20\%)].

Traditionally, cytotoxic chemotherapy, primarily with alkylating agents, has been used in patients with locally advanced or metastatic NENs, but it has been associated with variable efficacy depending on inherent tumoural characteristics [5-7]. Following the implementation of specific histopathological classification criteria, it became apparent that the primary site of origin, tumour differentiation, and the extent of the disease can affect prognosis and guide treatment. Although the major part of the information regarding the response of gastroenteropancreatic NENs to various treatments is derived from retrospective studies, randomized prospective studies have recently demonstrated a clinical benefit with molecular therapies targeting angiogenesis and the mTOR pathway, such as with sunitinib [8] and everolimus [9], in patients with advanced progressing pancreatic NENs (pNENs). Although targeted therapies yielded prolonged progression-free survival (PFS) in patients with pNENs, they are rarely associated with objective radiographic tumour shrinkage by Response Evaluation Criteria in Solid Tumors (RECIST) [10].

Although the role of cytotoxic chemotherapy in NENs has not been as well defined, its use is recommended in certain settings by guidelines for NEN management [11$14]$. In poorly differentiated NENs, a combination of plat- inum and etoposide is usually proposed as a gold standard - although based on old and relatively limited evidence [7]. It is more difficult to find a well-defined role for conventional chemotherapy in well-differentiated/ moderately differentiated NENs, where several agents, mainly 5-fluorouracil (5-FU), capecitabine (CAP), streptozocin (STZ), dacarbazine (DTIC), and oxaliplatin, have been studied [5]. Temozolomide (TMZ), a less toxic and oral derivative of intravenous DTIC, is an alkylating agent more commonly investigated in the context of low-/intermediate-grade NENs, but it has also been evaluated in high-grade NENs $[6,15,16]$. Brain and endocrine glands have different embryologic origin, as they are derived from the ectodermal and endodermal layers, respectively, but they share biologic pathways including resistance to available chemotherapeutic drugs. This is evident by the finding that low levels of the DNA repair enzyme $\mathrm{O}^{6}$ methylguanine-DNA methyltransferase (MGMT) are associated with sensitivity to TMZ in both NENs and glioblastomas [17].

The present review focuses on the current knowledge of TMZ in NENs, including its pharmacological and clinical aspects, possible predictive biomarkers, published and ongoing studies, and clinical experience.

\section{Pharmacology}

\section{Pharmacokinetics}

TMZ is a small molecule that is rapidly absorbed after oral administration with a bioavailability of approximately $100 \%$. The peak plasma concentration is obtained at a median time of maximal concentration of $1 \mathrm{~h}$. Food reduces TMZ absorption by $9 \%$, but this is not a clinically significant effect [18]. Because TMZ is highly lipophilic, it has a large mean volume of distribution of $0.41 / \mathrm{kg}$ and is able to cross the blood-brain barrier. Moreover, TMZ is promptly metabolized and eliminated with a mean halflife of about $1.8 \mathrm{~h}$ [18]. Within $8 \mathrm{~h}$, it is almost entirely cleared from plasma, exhibiting linear kinetics over the therapeutic dosing range of $75-250 \mathrm{mg} / \mathrm{m}^{2} /$ day $[19,20]$.

TMZ and its metabolites are excreted predominantly by the renal tubules, while cytochrome P450 enzymes play only a minor role. Pharmacokinetic studies have also shown that a creatinine clearance $<40 \mathrm{ml} / \mathrm{min}$ and hepatic impairment have a minimal effect on TMZ clearance [21]. TMZ does not accumulate in plasma with repeated and increasing dosing [18] and, unlike other alkylating agents that cross-link the DNA, causes less cumulative toxicity such as myelotoxicity $[19,20]$. 


\section{Pharmacodynamics}

Mechanism of Action

TMZ belongs to a novel class of alkylating agents which contain an imidazole ring and is structurally and functionally similar to DTIC. It is a prodrug, highly stable at the acid $\mathrm{pH}$ values of the stomach, but in the presence of slightly alkaline $\mathrm{pH}$ values, such as in blood and tissues, it undergoes spontaneous hydrolysis to the active compound 5-(3-methyltriazen-1-yl)imidazole-4-carboxamide (MTIC), which is further degraded to reactive methyldiazonium ions. The therapeutic benefit with TMZ depends on its ability to alkylate/methylate DNA, which most often occurs at the $\mathrm{N}^{7}$ and $\mathrm{O}^{6}$ positions of guanine residues, causing base pair mismatch (fig. 1). This methylation damages the DNA, and when mismatch repair (MMR) enzymes attempt to remove the $\mathrm{O}^{6}$-methylguanine adduct, they produce single- and double-strand breaks in the DNA, triggering cell death by apoptosis [18].

\section{Resistance}

Three main DNA repair mechanisms are involved in TMZ resistance [22]: MGMT, the MMR system, and the poly(ADP)-ribose polymerase (PARP) pathway, which is responsible for base excision repair (fig. 2). Primary resistance to TMZ is directly related to high MGMT expression [23], while the secondary mechanism is related to the MMR system in MGMT-lacking cells [24]. The third mechanism depends on the PARP pathway, which is involved in removing mainly $\mathrm{N}^{7}$-methylguanine and $\mathrm{O}^{3}$-methyladenine adducts. The base excision repair pathway seems to have a marginal role compared to the MGMT and MMR pathways, since the removal of $\mathrm{N}^{7}$ - and $\mathrm{O}^{3}$-methyl adducts does not result in DNA double-strand breaks [18,25].

\section{Interactions with Other Drugs}

Since TMZ is weakly bound to human plasma proteins and its metabolism is minimally affected by cytochrome $\mathrm{P} 450$, an interaction with other drugs is quite uncommon. A population analysis indicated that administration of valproic acid (VPA) decreases the clearance of TMZ by about $5 \%$, which corresponds to the rate of TMZ metabolized by the liver. Interestingly, a combination of VPA and TMZ in vitro seems to enhance its anti-tumour effect in TMZ-resistant glioblastoma multiforme (GBM) cells, which correlates with a VPA-mediated, reduced MGMT expression [26].

\section{MGMT and TMZ}

MGMT is a protein encoded by a gene located on chromosome band 10q26, which is crucial for genome stabil-

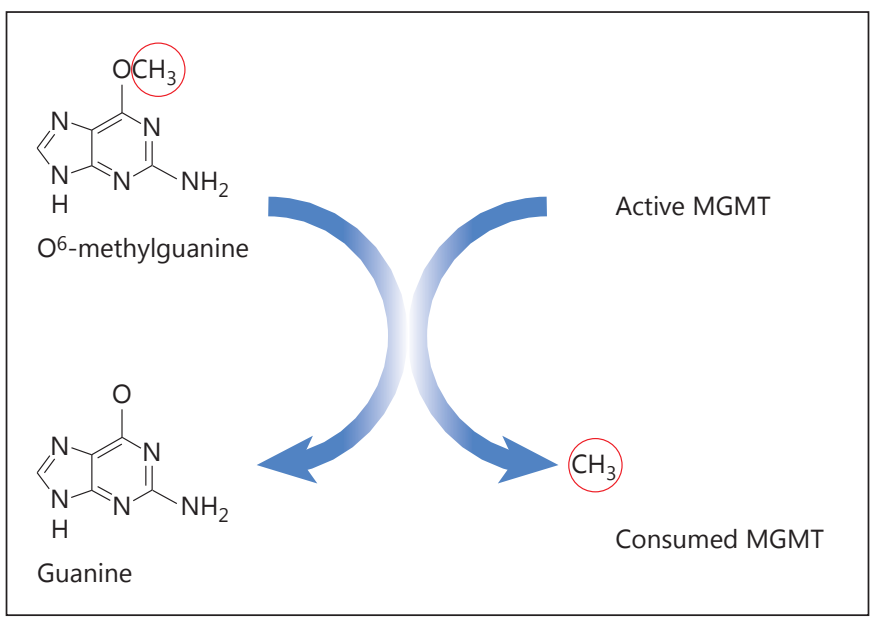

Fig. 1. Mechanism of action of TMZ.

ity [27]. It repairs the naturally occurring mutagenic DNA lesion $\mathrm{O}^{6}$-alkylguanine back to guanine and prevents mismatch and errors during DNA replication and transcription. Accordingly, loss of the MGMT gene increased the carcinogenic risk in mice after exposure to alkylating agents [28]. Alkylation DNA damage triggers the MMR system, leading to cell apoptosis. Although alkylating drugs preferentially modify the guanine base at the $\mathrm{N}^{7}$ position, $\mathrm{O}^{6}$-alkylguanine seems to be the main carcinogenic lesion in the DNA. MGMT is not a true enzyme, since it removes the alkyl group from the lesion in a stoichiometric reaction and the active enzyme is not regenerated after it has been alkylated ('suicide enzyme') [29] (fig. 1).

MGMT protein expression and MGMT methylation rates seem to be different in several GI-NENs and pNENs. MGMT deficiency as assessed by immunohistochemistry (IHC) ranges from 24 to $51 \%$ in pNENs $[17,30]$, while no case of MGMT deficiency has so far been recorded in GINENs [17]. In a retrospective study of 110 patients with NET treated with TMZ-based chemotherapy, 21 patients had tissue evaluable for MGMT IHC; partial responses (PR) were observed in 4 of the 5 patients with deficient MGMT (all pancreatic) but in none of the 16 patients showing intact MGMT [17]. On the other hand, Strosberg and co-workers found no significant correlation between MGMT IHC and tumour response in 59 patients with pNETs treated with TMZ combined with CAP (Strosberg, ENETS 2015, H16 poster). By contrast, MGMT methylation appears to be more common in other GI-NENs than in pNENs ( 25 vs. $0 \%, \mathrm{p}=0.03$ ) [31]. 
Fig. 2. Mechanisms of resistance to TMZ.

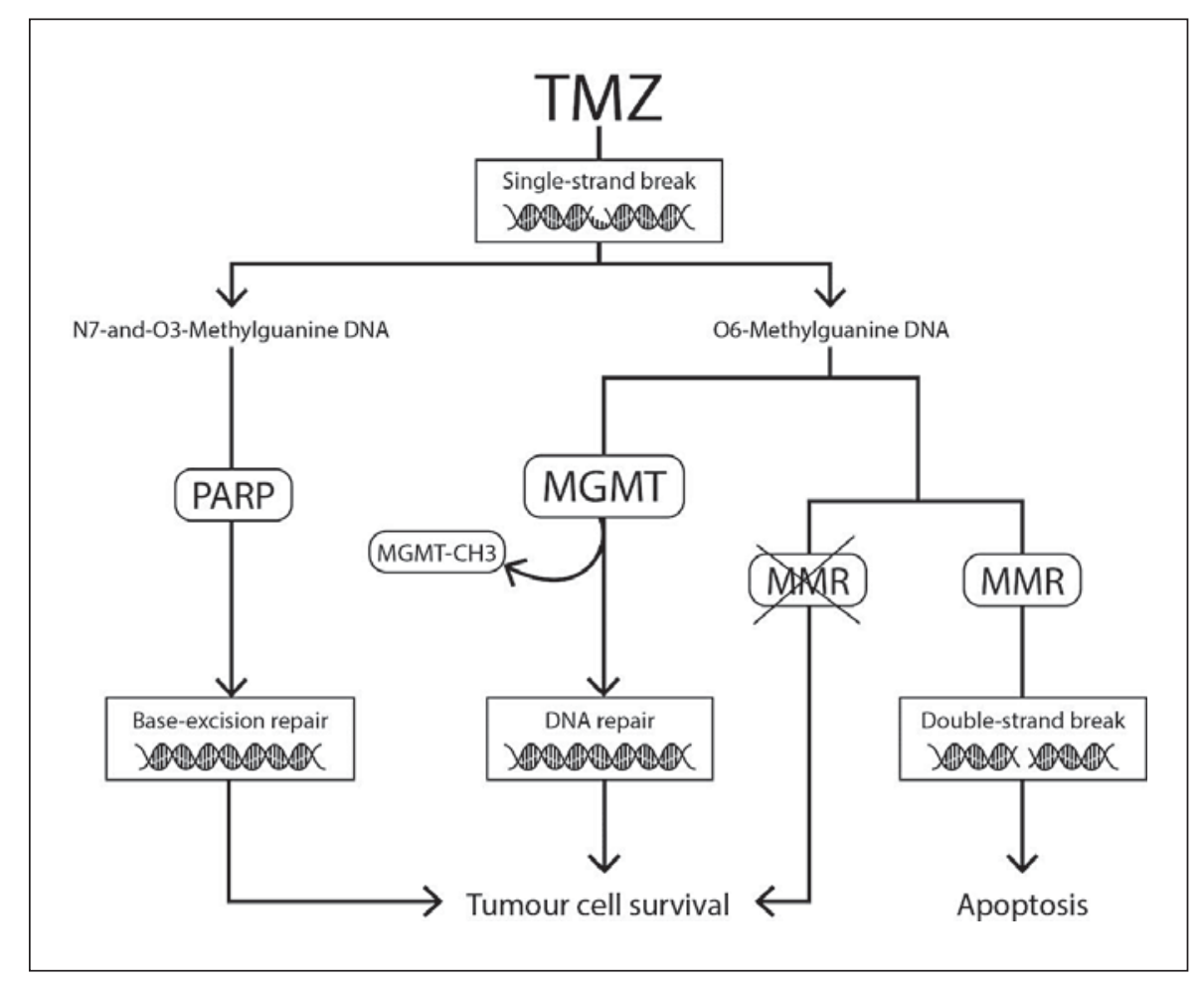

However, in a retrospective cohort study in which 15/93 (16.1\%) of the tumours exhibited methylated MGMT, no significant difference was reported between NENs originating from the foregut and those from the midgut [32]. So far, no study comparing MGMT expression as assessed by IHC with MGMT methylation in other GINENs or pNENs has been reported.

Furthermore, MGMT methylation as assessed by methylation-specific polymerase chain reaction (MSP) is a very rare finding in poorly differentiated GI-NECs and does not seem to compromise the effect of TMZ. In a retrospective study of 25 patients with NECs receiving second-line TMZ-based therapy, MGMT methylation was found only in 1 out of 20 patients. This patient was also negative for MGMT expression as assessed by IHC and was responsive to TMZ. The overall objective response was $71 \%$, showing that TMZ may be successfully used in NECs regardless of the MGMT methylation status [16]. No data on IHC in GI-NECs are currently available.

\section{MGMT Detection Methods}

The two main techniques for MGMT status detection include MGMT protein expression assessment by IHC and molecular analysis of $M G M T$ gene promoter methylation by polymerase chain reaction (PCR). IHC is a sim- ple, low-cost, and practical method commonly used in diagnostic histopathology that identifies protein expression patterns in heterogeneous areas within a tumour; MGMT staining in endothelial cells adjacent to or within the tumour can provide an internal positive control [17, 33]. One study found no significant difference in the response rate (RR) to TMZ according to MGMT protein expression [34], while another study reported a trend toward improved PFS and overall survival (OS) in patients with MGMT protein deficiency [17]. Observer variability and the lack of a clear association with patient survival have called into question the value of MGMT protein expression assessment by IHC and impeded its use as a clinical biomarker for the prediction of response to alkylating therapy [35].

Since IHC detection of MGMT protein expression lacks standardization and reproducibility, determination of gene silencing by PCR has been explored as an alternative mechanism to assess MGMT status. Retrospective translational studies of MGMT promoter methylation in GBM patients have consistently shown that patients with $M G M T$ gene silencing benefit from TMZ treatment [36]. A recent prospective randomized study employing MSP indicated a statistically significantly higher PFS of TMZretreated GBM patients with methylated MGMT pro- 
moter [37]. Until recently there has been a paucity of information regarding MGMT gene silencing by promoter hypermethylation in NENs. A new retrospective study reported data on $53 \mathrm{NEN}$ patients treated with alkylating agents such as TMZ, STZ, and DTIC [38]. Tumour tissue was analysed by MSP and pyrosequencing for MGMT promoter methylation and by IHC for MGMT protein expression. Both PFS and OS following the first therapy with alkylating agents (TMZ, DTIC, and STZ) were prolonged in patients with MGMT protein loss. This study provides important information on the role of MSP and pyrosequencing, highlighting the need for prospective, randomized studies to address these associations. Another retrospective analysis, presented by Strosberg et al. [39] at the 2015 ENETS meeting, showed no correlation between MGMT IHC and tumour response in 59 out of 144 pNET patients treated with TMZ and CAP.

\section{TMZ in pNENs}

Compared to other NENs, pNENs show higher RR to cytotoxic chemotherapy, particularly to STZ - an agent approved 30 years ago, either as monotherapy [40] or in combination with doxorubicin - and/or 5-FU [41]. Although early prospective studies using poorly defined histopathological classification criteria and means of assessing response to treatment demonstrated high RR of pNENs to STZ and DTIC/doxorubicin/5-FU-based chemotherapy, recent important retrospective studies using RECIST criteria have revealed an RR of approximately $40 \%[42,43]$.

Another active drug that has demonstrated activity in pNENs is DTIC. A phase II Eastern Cooperative Oncology Group (ECOG) study investigated the effect of 850 $\mathrm{mg} / \mathrm{m}^{2}$ DTIC intravenously in 50 patients with advanced pNENs and showed an overall RR of 33\% [44]. However, this regimen was associated with severe toxicity, with 2 deaths and cases of grade IV toxicity, mainly haematologic.

More recently, TMZ was shown to exhibit comparable overall RR in the treatment of NENs, albeit with less toxicity $[15,34]$. Based on the good RR and tolerability, TMZ has gained a primary role in pNEN treatment, both alone and in combination with other cytotoxic or targeted agents that may have a synergistic effect. Based on the high vascularity of NENs, one of the first prospective TMZ studies investigated the combination of TMZ (at a median dose of $150 \mathrm{mg} / \mathrm{m}^{2}$ on days $1-7$ and $15-21$ ) and thalidomide (at a median dose of $100 \mathrm{mg}$ daily) in 29 pa- tients with a variety of NENs, including 11 pNENs. An RR of $45 \%$ among pNENs using RECIST criteria and a median duration of response in the entire population of 13.5 months was obtained [45].

Another antiangiogenic-based combination is that of TMZ and bevacizumab (BVZ) reported in one phase II and one retrospective study $[46,47]$. In the phase II study, 34 patients (including 15 with pNENs) were treated with TMZ (at $150 \mathrm{mg} / \mathrm{m}^{2}$ orally per day on days $1-7$ and days 15-21) together with BVZ (at a dose of $5 \mathrm{mg} / \mathrm{kg}$ intravenously on days 1 and 15 of each 28 -day cycle). In the subset of patients with pNENs, the radiological RR was 33\% (5 PR of 15\%), PFS was 14.3 months, and OS was 41.7 months [47]. In a retrospective study, a metronomic schedule of $100 \mathrm{mg}$ TMZ daily, combined with BVZ at 7.5 $\mathrm{mg} / \mathrm{kg}$ every 21 days along with octreotide LAR at $30 \mathrm{mg}$ monthly, was administered to 15 patients with NENs (7 with pNENs) [46]. The overall RR according to RECIST criteria was $64 \%$ and with respect to pNENs included 1 complete response (CR), 4 PR, 1 stable disease (SD), and 1 progressive disease (PD). However, no assessment of the MGMT status was available in both of these studies. Although the number of patients treated was small, the metronomic schedule had fewer side effects and higher $\mathrm{RR}$, probably due to the continuous low-dose TMZ that may saturate MGMT and enhance TMZ sensitivity [48]. In addition, metronomic $\mathrm{TMZ}$ administration seems to inhibit angiogenesis and vasculogenesis by continuously exposing the more slowly proliferating endothelial cells of the tumour to the damaging action of the cytotoxic therapy [49].

Single-agent TMZ therapy, at a dose of $200 \mathrm{mg} / \mathrm{m}^{2}$ on days $1-5$ every 28 days until disease progression or intolerable toxicity development, has also been explored in 7 pretreated pNEN cases with disease progression, achieving a median survival of 7.0 months in the second-line setting [50]. Another interesting combination has recently been published and included the administration of the mTOR inhibitor everolimus with TMZ. Forty-three patients with pNEN were treated with TMZ at a dose of 150 $\mathrm{mg} / \mathrm{m}^{2}$ per day on days $1-7$ and days $15-21$ in combination with everolimus at $10 \mathrm{mg}$ daily in each 28 -day cycle for 6 months. Among 40 evaluable patients, 16 (40\%) experienced a PR; PFS was 15.4 months, although OS was not reached at the time of analysis [51].

In a retrospective study, 30 patients with metastatic, mostly well-differentiated or moderately differentiated pNENs received first-line therapy with CAP (at $750 \mathrm{mg} /$ $\mathrm{m}^{2}$ twice daily on days $1-14$ ) and TMZ (at $200 \mathrm{mg} / \mathrm{m}^{2}$ once daily on days $10-14$ every 28 days). Twenty-one pa- 
tients (70\%) achieved an overall response (0 CR, 21 PR, 8 $\mathrm{SD}$, and $1 \mathrm{PD}$ ), while their PFS was 18 months and the survival rate at 2 years was $92 \%$ [15]. A synergistic relationship between CAP and TMZ has been postulated. A preliminary study has suggested that metastatic pNENs express low levels of MGMT [17], potentially explaining the high RR of TMZ in pNENs. Additionally, the DNA damage induced by CAP through incorporation of 5-fluorodeoxyuridine triphosphate into the DNA and reduction of thymidine pools by inhibition of thymidylate synthase via 5-fluorodeoxyuridine monophosphate may reduce the repair activity of MGMT, thereby potentiating the effects of TMZ on the DNA strand [15, 52-54]. A second retrospective study evaluated 18 pretreated patients with a broad range of metastatic NENs (GI and pancreatic) who received $600 \mathrm{mg} / \mathrm{m}^{2}$ of CAP orally twice daily on days 1-14 (max. 1,000 mg orally twice daily) and TMZ at $150-200 \mathrm{mg} / \mathrm{m}^{2}$ divided into 2 doses daily on days 10-14 of a 28-day cycle [53]. Although it is difficult to extrapolate precise data on pNENs, the total RR was 64\% (1 CR, 10 PR, 4 SD, and 3 PD), PFS was 14.0 months, and $O S$ from the diagnosis of liver metastases was 83 months. The MGMT status was not evaluated, but the rationale of this scheme was based on in vitro data suggesting that twice-daily TMZ dosing may be superior to once-daily dosing because the first dose depletes MGMT levels, thus allowing the second dose to methylate guanines with a decreased repair capacity from MGMT [55]. A third retrospective study evaluated 7 patients with metastatic pNENs who were treated with CAP at a flat dose of 1,000 mg orally twice daily on days $1-14$ and TMZ at $200 \mathrm{mg} / \mathrm{m}^{2}$ in 2 divided doses daily on days $10-14$ of a 28 day cycle [56]. Three patients achieved a PR, and 2 reached $\mathrm{SD}$. The total RR was $43 \%$, a clinical benefit was noted in $71 \%$ of the cases, and the median duration of response was 8 months. In the later study, MGMT analysis was not carried out.

Based on these encouraging results, the interest in the effect that TMZ may exert on pNENs is evolving. In a prospective study, 28 patients ( 11 with pNENs) received $\mathrm{CAP}$ at $1,500 \mathrm{mg} / \mathrm{m}^{2} /$ day divided into 2 daily doses (max. $2,500 \mathrm{mg}$ /day) on days $1-14$ and TMZ at $150-200 \mathrm{mg} / \mathrm{m}^{2}$ divided into 2 daily doses on days 10-14, with 2 weeks off in a 28-day cycle. Four patients with pNENs (36\%) showed a PR, 6 (55\%) SD, and 1 (9\%) PD; PFS was longer than 18.2 months [57]. Another retrospective study tested the same regimen in 29 patients, 14 of whom had well-differentiated pNENs. The overall RR was $14 \%$, and $59 \%$ of the patients showed SD. Of note, all patients with PR had $M G M T$ gene inactivation and TS polymorphism, sug-

Temozolomide in NENs gesting that it could serve as a predictive biomarker [58]. A third retrospective study tested a slightly higher chemotherapy dose including CAP at $2,000 \mathrm{mg} / \mathrm{m}^{2} /$ day divided into 2 daily doses on days 1-14 and TMZ at $200 \mathrm{mg} /$ $\mathrm{m}^{2}$ on days $10-14$ of each 28 -day cycle. Of the 29 patients included, 14 had pNENs. Although RR were not reported, PFS and OS of the pNEN patients was 4.9 and 18.8 months, respectively [59]. Another interesting prospective study included 35 patients with advanced NENs who received $7.8 \mathrm{GBq}$ of ${ }^{177} \mathrm{Lu}$-octreotate every 8 weeks, with 14 days of CAP at $1,500 \mathrm{mg} / \mathrm{m}^{2}$ for 4 cycles and $200 \mathrm{mg} /$ $\mathrm{m}^{2}$ of TMZ in the last 5 days of each CAP cycle. Although no specific RR was reported for pNENs, the overall responses in GI-NENs were CR in $16 \%$, PR in $41 \%$, SD in $37 \%$, and PD in $6 \%$ of the patients [60]. More recently, a multicentre, retrospective study on NECs has expanded currently existing treatment options for such tumours beyond platinum-based chemotherapy [61], as patients with a $\mathrm{Ki}-67 \mathrm{LI}<55 \%$ were more responsive to TMZ than to platinum-based chemotherapy [62].

The majority of these studies have limitations including a relatively small number of patients treated, heterogeneity of the tumour characteristics, and differences in the regimens applied and responses observed. Furthermore, while most of the studies to date have evaluated TMZ in combination with other agents, the relative efficacy of these combinations compared to TMZ alone has not been formally evaluated. The combination most widely studied has been the combination of CAP and TMZ (table 1). Whether this combination is in fact superior to TMZ alone is uncertain. This question is currently being addressed in an ongoing clinical trial (NCT01824875) entitled TMZ with or without CAP in Treating Patients with Advanced pNENs.

\section{TMZ in Thoracic NENs}

So far, around 150 patients with thoracic (lung and thymic) NENs have been reported in retrospective and prospective studies of TMZ-based chemotherapy $[16,17$, $34,46,47,63-68$ ] (table 2). TMZ as a single agent was tested in 20 patients, 13 with bronchial and 7 with thymic NENs, as a part of a retrospective analysis of 36 pretreated patients with advanced NENs [34]. In this series, TMZ was mostly given when all other treatment options had failed, obtaining a $67 \%$ overall rate of clinical benefit (PR and SD), with lung NENs achieving $31 \mathrm{PR}$ and $31 \% \mathrm{SD}$, whereas thymic NENs showed $71 \%$ SD. The overall time to progression was 7 months, with no difference between 
Table 1. TMZ regimens and responses in pNENs assessed by RECIST criteria

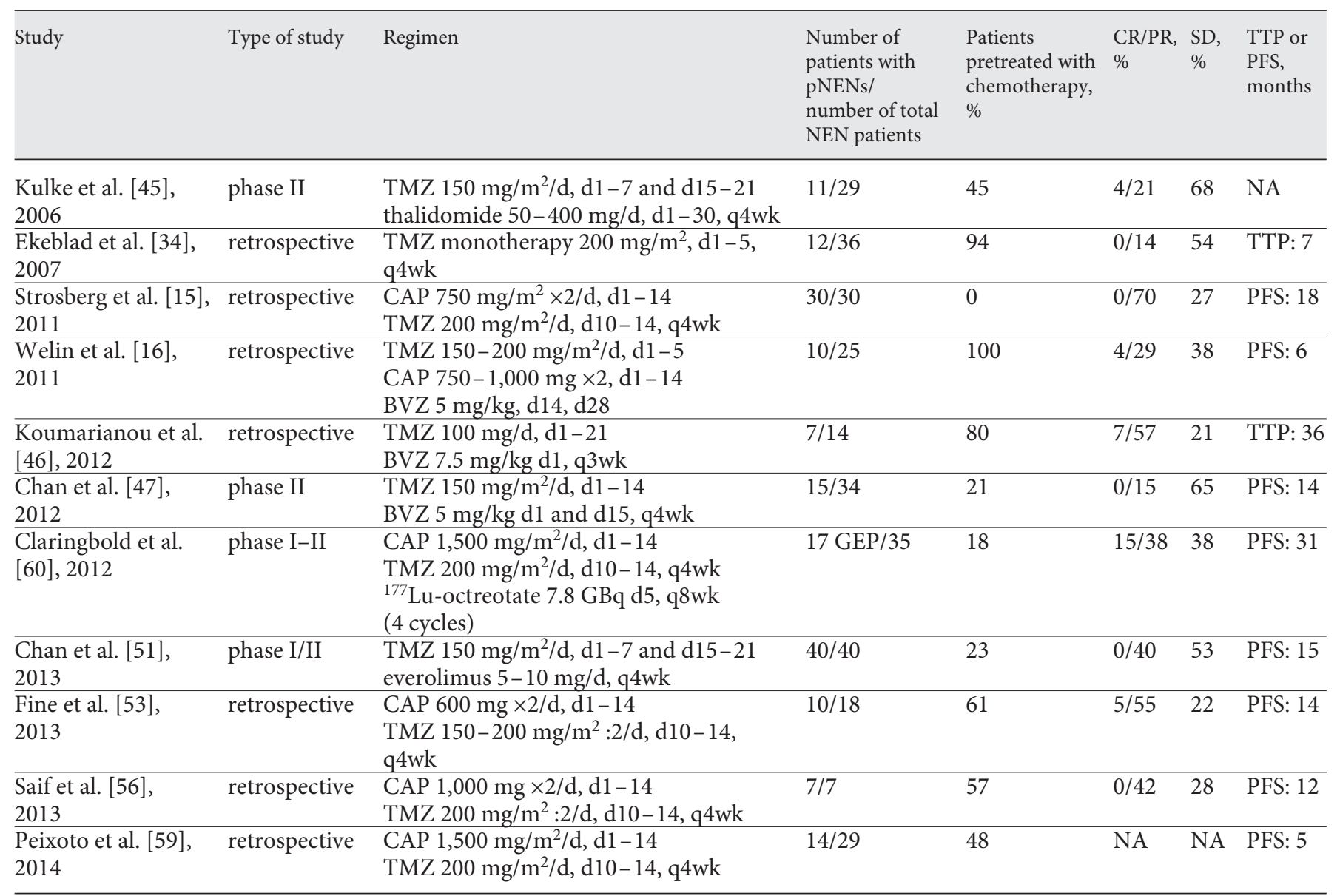

$\mathrm{TTP}=$ Time to progression; GEP = gastroenteropancreatic; $\mathrm{d}=$ day; $\times 2=$ twice; $: 2=$ divided into 2 doses; $\mathrm{q} 3 / 4 / 8 \mathrm{wk}=$ every $3 / 4 / 8$ weeks; NA = data not available.

thoracic NENs and pNENs. MGMT status as evaluated by IHC did not correlate with the primary tumour site, and no significant difference in overall RR was found between tumours with high and those with low MGMT protein expression. In another study, 25 patients with NECs progressive on first-line, mainly platinum-based chemotherapy were treated with a TMZ-based regimen. Among these patients were 3 with atypical lung carcinoids with a Ki-67 LI >20\% [16]. Although specific results for lung NENs were not reported, the 16 patients with Ki-67 LI $<60 \%$ and positive somatostatin receptor scintigraphy were more responsive than the others. In a further study that used metronomic TMZ in 15 patients, 1 patient with a lung NEN showed PD [46]. In the phase II trial that included 34 patients with NENs of different tissue origin treated with $\mathrm{TMZ}$ and $\mathrm{BVZ}, 12 \%$ of the patients had lung
NENs, but specific results regarding the RR and the survival times of this subgroup were not reported [47]. Over the last 3 years, six small studies have been published describing results of TMZ-based therapy in homogeneous thoracic NEN populations: two on bronchial, two on small cell, and two on thymic NENs [63-68] (table 2). The bronchial NEN studies included 45 patients treated with TMZ monotherapy and showed a $66-71 \%$ clinical benefit rate and a 5- to 10 -month PFS $[63,66]$. In the thymic group, 13 patients treated with TMZ and CAP showed a $90-100 \%$ clinical benefit rate $[64,65]$. In the small cell lung cancer group, 89 patients were treated with either a 5 -day or a 21 -day TMZ regimen, achieving a $12-23 \%$ overall RR $[67,68]$.

Although the relatively small size of the above studies limits the interpretation of the results and specific data 
Table 2. TMZ regimens and responses in thoracic NENs assessed by RECIST criteria

\begin{tabular}{|c|c|c|c|c|c|c|c|}
\hline $\begin{array}{l}\text { Ekeblad et al. [34], } \\
2007\end{array}$ & retrospective & TMZ $200 \mathrm{mg} / \mathrm{m}^{2} / \mathrm{d}, \mathrm{d} 1-5, \mathrm{q} 4 \mathrm{wk}$ & $\begin{array}{l}20 / 36 \text { ( } 7 \text { thymic, } \\
13 \text { bronchial) }\end{array}$ & NA & $0 / 31$ & 25 & TTP: 7 \\
\hline $\begin{array}{l}\text { Welin et al. [16], } \\
2011\end{array}$ & retrospective & $\begin{array}{l}\text { TMZ } 150-200 \mathrm{mg} / \mathrm{m}^{2} / \mathrm{d}, \mathrm{d} 1-5 \\
\text { CAP } 750-1,000 \mathrm{mg} \times 2, \mathrm{~d} 1-14 \\
\text { BVZ } 5 \mathrm{mg} / \mathrm{kg}, \mathrm{d} 14, \mathrm{~d} 28\end{array}$ & 3/25 (bronchial) & 100 & 32 & 40 & PFS: 6 \\
\hline $\begin{array}{l}\text { Koumarianou et al. } \\
{[46], 2012}\end{array}$ & retrospective & $\begin{array}{l}\text { TMZ } 100 \mathrm{mg} / \mathrm{d}, \mathrm{d} 1-21 \\
\text { BVZ } 7.5 \mathrm{mg} / \mathrm{kg}, \mathrm{d} 1, \mathrm{q} 3 \mathrm{wk}\end{array}$ & 1/15 (bronchial) & 80 & 0 & 0 & TTP: 9 \\
\hline $\begin{array}{l}\text { Chan et al. [47], } \\
2012\end{array}$ & prospective & - & 4/34 (bronchial) & NA & NA & NA & NA \\
\hline $\begin{array}{l}\text { Crona et al. [65], } \\
2013\end{array}$ & retrospective & $\begin{array}{l}\text { TMZ } 150-200 \mathrm{mg} / \mathrm{m}^{2} / \mathrm{d}, \mathrm{d} 1-5, \\
\text { q4wk ( } \pm \text { sorafenib } 1 \text { patient, } \\
\pm \text { CAP/BVZ } 1 \text { patient })\end{array}$ & $10 / 28$ (thymic) & NA & $0 / 20$ & 70 & TTP: 20 \\
\hline $\begin{array}{l}\text { Saranga-Perry et al. } \\
{[64], 2013}\end{array}$ & retrospective & $\begin{array}{l}\text { TMZ } 170-190 \mathrm{mg} / \mathrm{m}^{2} / \mathrm{d}, \mathrm{d} 10-14 \\
\text { CAP } 600-750 \mathrm{mg} / \mathrm{d} \times 2, \mathrm{~d} 1-14\end{array}$ & 3/3 (thymic) & 100 & 67 & 33 & NA \\
\hline $\begin{array}{l}\text { Chong et al. [66], } \\
2014\end{array}$ & retrospective & $\begin{array}{l}\text { TMZ } 150-200 \mathrm{mg} / \mathrm{m}^{2} / \mathrm{d}, \mathrm{d} 1-5, \\
\text { q4wk }\end{array}$ & $\begin{array}{l}14 / 300 \\
\text { (bronchial) }\end{array}$ & NA & 14 & 57 & PFS: 10 \\
\hline $\begin{array}{l}\text { Pietanza et al. [67], } \\
2012\end{array}$ & phase II & TMZ 75 mg/m²/d, d1-21, q4wk & 64 (SCLC) & 100 & $1.5 / 19$ & 9 & TTP: 1.6 \\
\hline $\begin{array}{l}\text { Zauderer et al. [68], } \\
2014\end{array}$ & phase II & TMZ $200 \mathrm{mg} / \mathrm{m}^{2} / \mathrm{d}, \mathrm{d} 1-5$, q4wk & 25/25 (SCLC) & 100 & $0 / 12$ & NA & NA \\
\hline
\end{tabular}

TTP = Time to progression; $\mathrm{d}=\mathrm{day} ; \times 2=$ twice; $\mathrm{q} 3 / 4 \mathrm{wk}=$ every $3 / 4$ weeks; $\mathrm{NA}=$ data not available; SCLC $=$ small cell lung cancer.

regarding lung NENs are not available, non-pancreatic primaries seemed to be less responsive to the TMZ regimen than pNENs. Additionally, TMZ-based chemotherapy seems to be somewhat more active in patients with bronchial and thymic NENs as compared to small cell lung cancer. However, in order to substantiate its efficacy, a specific prospective study of lung and thymic NENs with TMZ as a single agent or in combination is warranted; in such a study, an ancillary biological analysis should be included to validate the potential predictive role of MGMT expression.

\section{TMZ in NENs from Other Primary Sites}

\section{Malignant Chromaffin Cell Tumours}

Chromaffin cell tumours (phaeochromocytomas and paragangliomas) were initially considered to be relatively benign, but recent studies have documented that approximately $30 \%$ (mainly paragangliomas) may follow a truly malignant course, whereas $25-30 \%$ may develop in the context of familial syndromes [69]. Several indices have been used to predict their malignant potential, including succinate dehydrogenase B (SDHB) mutations, which carry the highest risk. Treatment options for these patients are relatively limited, although radiopharmaceuticals with either ${ }^{131}$ I-metaiodobenzylguanidine or ${ }^{90} \mathrm{Y}$ - or ${ }^{177} \mathrm{Lu}$-radiolabelled octreotide have elicited some meaningful responses [70]. Chemotherapy using a cyclophosphamide-DTIC-vincristine regimen is currently recommended for the treatment of malignant phaeochromocytoma and paraganglioma (MPP) [69]. Due to relatively low RR to these modalities, TMZ was used for the first time in a phase II study in 3 patients with MPP, employing the combination of TMZ (at $150 \mathrm{mg} / \mathrm{m}^{2}$ for 7 days followed by a 7-day rest) and thalidomide (administered at doses of 50-400 mg without discontinuation for 28 days) [45]. Since then, only sporadic case reports using TMZ either alone or in combination with other agents have appeared, demonstrating a potential benefit $[71,72]$. A recent French retrospective multicentre study investigated the response to TMZ monotherapy (at a 
mean dose intensity of $172 \mathrm{mg} / \mathrm{m}^{2} /$ day for 5 days every 28 days) in 15 consecutive patients with documented progressive MPP for whom information regarding $S D H B$ mutation and $M G M T$ promoter methylation and MGMT IHC was available $[10$ patients $(67 \%)$ carried an $S D H B$ mutation] [13]. Median PFS was 13.3 months after a median follow-up of 35 months. Five patients developed a PR (33\%), 7 SD (47\%), and 3 PD (20\%). PR were observed only in patients with $S D H B$ mutations. MGMT IHC was negative in the tumour samples from 4 patients who responded to treatment, whereas $S D H B$ germline mutation was associated with hypermethylation of the MGMT promoter and low expression of MGMT. This study demonstrated that TMZ is an effective anti-tumour agent in patients with SDHB-related MPP; its effectiveness is partially explained by the silencing of MGMT expression as a consequence of MGMT promoter hypermethylation in $S D H B$-mutated tumours. These data suggest that genotyping may guide the response to treatment with TMZ in MPP and provide a rationale for tailor-made treatment.

\section{Non-Pancreatic GI-NENs}

Non-pancreatic primary GI-NENs are heterogeneous and include tumours of midgut (small intestine and proximal colon), foregut (stomach and duodenum), and hindgut origin. Multiple studies indicate dramatically lower responses of GI-NENs to TMZ-based chemotherapy compared to pNENs $[45,47]$. One exception is a prospective study of CAP and TMZ (CAPTEM) in 28 patients, which reported an RR of $41 \%$ among 12 'carcinoid tumour' patients [57]. However, the specific primary sites of these patients were unclear, and further data are necessary to evaluate whether the CAPTEM combination is active in specific subtypes of GI-NENs.

\section{Treatment Schedules and Toxicity}

TMZ has been administered to patients with solid tumours for nearly 15 years in different schedules and dosages. In the published literature on NENs, TMZ has been administered in different combinations, dosages, and schedules to approximately 350 patients over time (table 3). There is retrospective and prospective evidence of activity, but due to the low number of patients included in the individual studies and the variety of regimens used, it is difficult to identify an optimal combination and schedule (table 3 ).

\section{Single Agent}

The recommended schedule for TMZ as a single agent comes from early clinical trials with TMZ conducted by the Cancer Research Campaign (now Cancer Research UK) and consists of an oral administration of $200 \mathrm{mg} / \mathrm{m}^{2}$ daily for 5 consecutive days repeated every 4 weeks [73]. The 5-day schedule was believed to enhance MGMT depletion and hence to sensitize MGMT-intact cells to the effects of the methylating agent [73]. The overall toxicity observed in the first NEN study with this schedule was as follows: $14 \%$ grade III thrombocytopenia, $9 \%$ grade III and IV fatigue, and 3\% grade IV neutropenia [34]. The most intensive schedule studied in clinical trials comprised TMZ administration in a 4-hour schedule to patients with metastatic melanoma, but the efficacy was not sufficiently enhanced and the toxicity was increased [73].

\section{Combinations}

The extent to which combination therapy may increase toxicity is difficult to assess, given the different dose schedules of TMZ used in various studies [45-47, 51, 57, 60, 67, $74,75]$ (table 1). One study included 29 NEN patients treated with a dose-dense schedule of TMZ at $150 \mathrm{mg} / \mathrm{m}^{2} /$ day on days 1-7 every other week and thalidomide at 200 $\mathrm{mg} /$ day. Although the treatment was effective, the study had $55 \%$ of the patients discontinuing treatment due to high toxicity, mainly grade III-IV lymphopenia. Three patients developed opportunistic infections, indicating a severe immunocompromising effect of the regimen [45]. Based on the fact that opportunistic infections occurred during TMZ-induced lymphopenia and that these patients had not received anti-infection prophylaxis, a recommendation to administer prophylactic sulfamethoxazole/trimethoprim was established for further studies with the same regimen. Additional clinical variables such as age, concurrent steroid treatment, poor nutritional status, and compromised performance status are also likely to increase the risk of infections. In addition, prophylactic antifungal and antiviral (mainly antiherpetic) drugs might be needed to control the infection risk or viral reactivation [76]. In a second prospective study combining TMZ (at $150 \mathrm{mg} / \mathrm{m}^{2}$ orally per day on days $1-7$ and days $15-21$ ) with BVZ (at a dose of $5 \mathrm{mg} / \mathrm{kg} /$ day intravenously on days 1 and 15 of each 28-day cycle) the most commonly observed toxicities were grade III or IV lymphopenia (53\%) and thrombocytopenia (18\%). Prophylactic antibiotics were included in this study, and only 1 patient developed an opportunistic infection [47]. A third study of TMZ in combination with everolimus also used the dose-intense schedule of TMZ at $150 \mathrm{mg} / \mathrm{m}^{2}$ for 7 days every other week 
Table 3. Schedules and dosages of TMZ in NENs

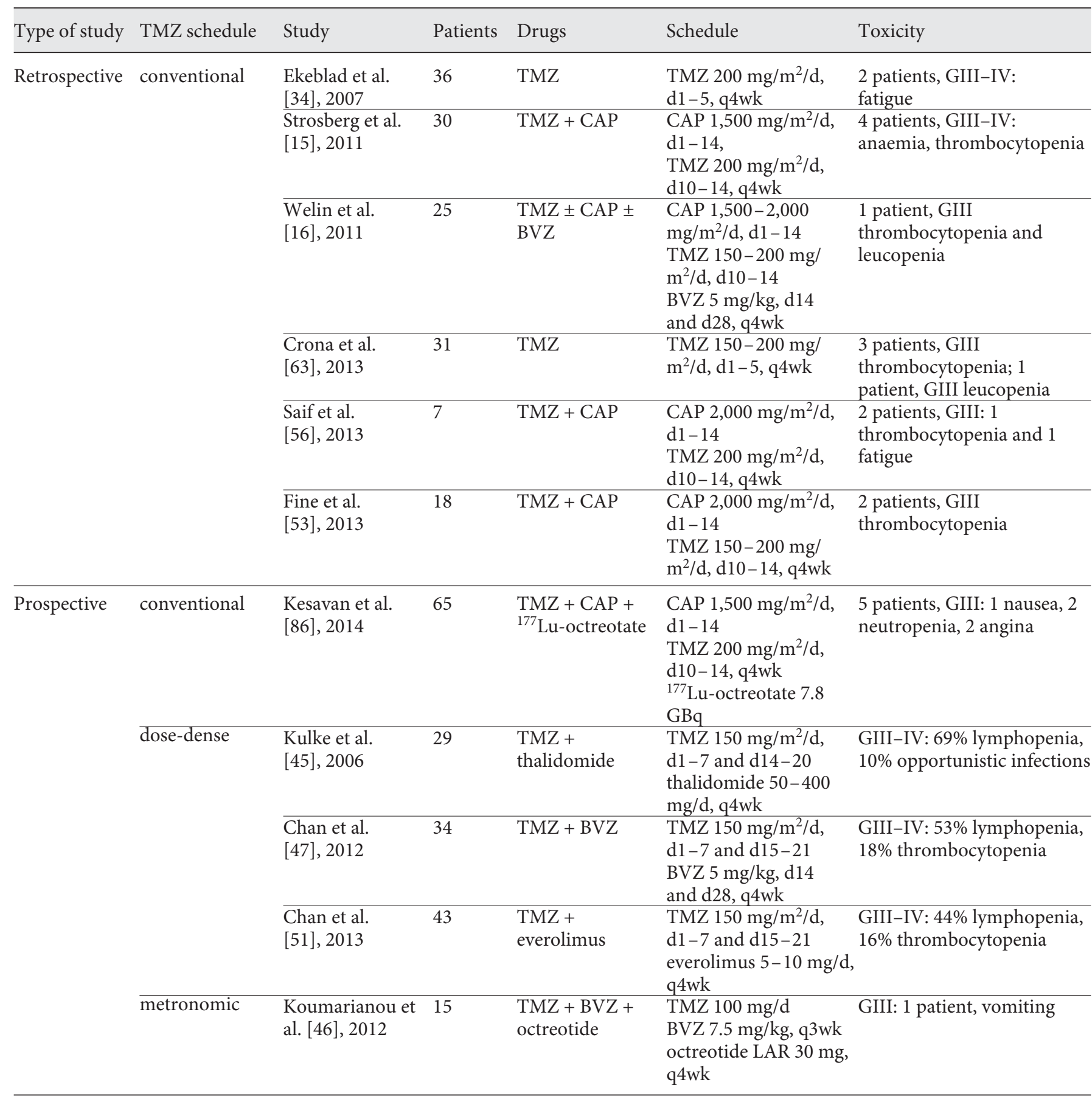

$\mathrm{d}=$ Day; q3/4wk = every 3/4 weeks.

[51]. Due to concerns regarding toxicity, TMZ was administered for a maximum of 6 months. This study showed that the combination of TMZ and everolimus was both active and well tolerated.
A study on GBM employing $75 \mathrm{mg} / \mathrm{m}^{2} \mathrm{TMZ}$ for 6 weeks every 8 weeks, analysed for lymphocyte subsets, showed protracted lymphopenia induced in $60 \%$ of the patients and affecting the $\mathrm{CD} 4^{+}$compartment preferen- 
tially [77]. TMZ given on a less dose-intense schedule at a dose of $200 \mathrm{mg} / \mathrm{m}^{2}$ for 5 consecutive days may be better tolerated, although prospective data are limited. For instance, in the CAPTEM study by Strosberg et al. [15] employing CAP at $750 \mathrm{mg} / \mathrm{m}^{2}$ twice daily on days $1-14$ and TMZ at $200 \mathrm{mg} / \mathrm{m}^{2}$ once daily on days $10-14$ every 28 days, despite the lack of antimicrobial prophylaxis, only 3 patients developed clinically non-significant infections ( 2 herpes zoster and 1 herpes labialis); toxicities included 2 grade IV haematologic cases (anaemia and thrombocytopenia) and 2 cases of grade III transaminasaemia. However, because this study was retrospective in nature, it is difficult to compare the relative toxicities to data from prospective trials. In a second CAPTEM study employing $600 \mathrm{mg} / \mathrm{m}^{2}$ of CAP orally twice daily on days 1-14 (max. 1,000 mg orally twice daily) and TMZ at 150$200 \mathrm{mg} / \mathrm{m}^{2}$ divided into 2 doses daily on days $10-14$ of a 28 -day cycle, the toxicity was mild and included 1 grade III toxicity (thrombocytopenia) [53]. Another combination study employing $7.8 \mathrm{GBq}$ of ${ }^{177} \mathrm{Lu}$-octreotate every 8 weeks, with 14 days of CAP at $1,500 \mathrm{mg} / \mathrm{m}^{2}$ for 4 cycles and $200 \mathrm{mg} / \mathrm{m}^{2}$ of TMZ on days $10-14$, resulted in 1 case of grade III nausea (3\%) and 2 cases of grade III neutropenia (6\%), whereas 2 patients developed angina (6\%) [60].

Other less common non-haematologic toxicities reported with the use of TMZ in NENs include GI side effects such as nausea, vomiting, diarrhoea, elevated aspartate transaminase/alanine transaminase and total bilirubin, as well as mucocutaneous toxicity such as skin rash and pruritus [45-47, 51, 57, 60, 67, 74, 75]. Additionally, some non-haematologic toxicities have been ascribed to the use of other agents used in combination with TMZ (e.g. hypertension and proteinuria related to the use of BVZ, hand and foot syndrome related to the use of CAP, and hyperglycaemia and hypercholesterolaemia related to the use of everolimus) [45-47, 51, 57, 60, 67, 74, 75]. Such toxicities have to be accounted for in patients with NENs.

\section{Schedules}

So far, various schedules with TMZ have been used. In GBM, a general consensus regarding the standard schedule has not been reached, even though the 5/28-day schedule seems the most commonly used. Other types of schedules, named 'dose-dense', 'prolonged', and 'metronomic', have been used, mainly outside clinical trials [78]. The dose-dense schedule is also called 'week on/week off and consists of TMZ at $150 \mathrm{mg} / \mathrm{m}^{2} /$ day over 7 days followed by 7 days of rest, repeated every 2 weeks (7/15-day schedule). The prolonged schedule is a $21 / 28$-day schedule, repeated on day 29 , using $75-100 \mathrm{mg} / \mathrm{m}^{2} /$ day over 21 days. The dose-dense and prolonged schedules have been compared in patients with advanced solid tumours. For the dose-dense schedule, the maximum tolerated dose was $150 \mathrm{mg} / \mathrm{m}^{2} /$ day. For the prolonged schedule, the maximum tolerated dose ranged from $85 \mathrm{mg} / \mathrm{m}^{2}$ daily in heavily pretreated patients to $100 \mathrm{mg} / \mathrm{m}^{2}$ daily in minimally pretreated patients. The authors concluded that the prolonged TMZ schedule depletes MGMT levels and may potentiate TMZ activity [79]. In another study, patients treated with TMZ $\left(100 \mathrm{mg} / \mathrm{m}^{2} /\right.$ day for 21 consecutive days every 28 days) for indications other than NEN experienced profound and prolonged lymphopenia with blood counts recovering to normal levels only after 12 weeks [80].

The metronomic schedule uses TMZ at $50 \mathrm{mg} / \mathrm{m}^{2} /$ day without interruption and is associated with minor toxicity [81]. In a phase I study, TMZ was administered for 6-7 weeks at a starting dose of $50 \mathrm{mg} / \mathrm{m}^{2}$ daily, with a planned escalation up to $100 \mathrm{mg} / \mathrm{m}^{2}$, in patients with GBM. Although the patients received an increased dose compared to the 5-day schedule, pharmacokinetic data showed activity with no plasma accumulation of TMZ and no further increase in toxicity [19]. In another metronomic study employing 100-mg TMZ capsules daily combined with BVZ at $7.5 \mathrm{mg} / \mathrm{kg}$ every 21 days along with octreotide LAR at $30 \mathrm{mg}$ monthly in 15 patients with NENs [46], haematologic toxicities were 2 cases of grade I neutropenia and 2 cases of grade II thrombocytopenia.

\section{Duration of Therapy}

For those patients who develop long-term responses to treatment, a question arises on how long to continue TMZ therapy. As TMZ is a DNA-damaging agent, development of secondary malignancies is a potential cause for concern. This concern has been sustained by the finding of a number of TMZ-treated GBM patients developing myelodysplastic syndrome, leukaemia, or aplastic anaemia [82-85]. While no such toxicities have been reported in NEN patients, this may be due to the relative lack of prospective data and long-term follow-up in NEN patients treated with TMZ. There are no recommendations regarding the maximum duration of therapy, but a 1 - to 39 -month duration of treatment has been reported [15, $34,45,47,53,59]$. 


\section{Ongoing Clinical Trials of TMZ in NENs}

1 A phase II study from Stanford University, USA (NCT01525082): CAP, Temozolomide and Bevacizumab for Metastatic or Unresectable Pancreatic Neuroendocrine Tumors

2 A phase I/II study from Northwestern University, USA (NCT01465659): Temozolomide and Pazopanib Hydrochloride in Treating Patients with Advanced Pancreatic Neuroendocrine Tumors That Cannot Be Removed by Surgery

3 A randomized phase II study from the ECOG and National Institutes of Health, USA (NCT01824875): Temozolomide with or without Capecitabine in Treating Patients with Advanced Pancreatic Neuroendocrine Tumors

4 A phase II study from Haukeland University Hospital, Norway, and collaborators from the Nordic countries (NCT02248012): Everolimus and Temozolomide in Advanced Gastroenteropancreatic Neuroendocrine Carcinoma (G3)

\section{Conclusions}

TMZ has shown activity as a single agent or in combination with other drugs in approximately 450 patients with advanced NENs. However, the majority of the data is derived from observational and small, single-institution, prospective phase II studies using a variety of differ- ent TMZ dose schedules. The combination of CAPTEM is a commonly employed regimen, and has been associated with objective responses in either chemotherapy-naive and/or heavily pretreated patients mainly with pNENs, although NENs from other GI sites and non-GI primaries may also be responsive. Currently, there are no data comparing the efficacy of this regimen to other TMZ-based combinations or to TMZ alone, nor are there prospective data comparing this regimen to STZ-based therapies. Although determination of the MGMT status has been suggested as a predictive biomarker of response, its role remains still investigational, awaiting validation along with the establishment of the optimal detection method.

In conclusion, although TMZ appears to be a promising agent for the management of advanced NENs, there are several open questions regarding the timing of therapy, optimal schedule, duration of treatment, and longterm toxicity that should be studied in prospective trials. Large multicentre, randomized, prospective studies are needed to substantiate its use and possible role in the adjuvant and neoadjuvant setting in advanced well-differentiated and poorly differentiated NENs.

\section{Disclosure Statement}

The authors declare that there is no conflict of interest that could be perceived as prejudicing the impartiality of the research reported. This study did not receive any specific grant from any funding agency in the public, commercial, or not-for-profit sector.

\section{References}

1 Modlin IM, Lye KD, Kidd M: A 5-decade analysis of 13,715 carcinoid tumors. Cancer 2003;97:934-959.

2 Modlin IM, Moss SF, Gustafsson BI, Lawrence B, Schimmack S, Kidd M: The archaic distinction between functioning and nonfunctioning neuroendocrine neoplasms is no longer clinically relevant. Langenbecks Arch Surg 2011;396:1145-1156.

3 Klöppel G: Classification and pathology of gastroenteropancreatic neuroendocrine neoplasms. Endocr Relat Cancer 2011;18(suppl 1):S1-S16.

4 Rindi G, Arnold R, Bosman F, Capella C, Klimstra D, Klöppel G, Komminoth P, Solcia E: Nomenclature and classification of neuroendocrine neoplasms of the digestive system; in Bosman FT, Carneiro F, Hruban RH, Theise ND (eds): WHO Classification of Tumours of the Digestive System. Lyon, IARC, 2010, pp 13-14.
5 Basu B, Sirohi B, Corrie P: Systemic therapy for neuroendocrine tumours of gastroenteropancreatic origin. Endocr Relat Cancer 2010; 17:R75-R90.

6 Koumarianou A, Chatzellis E, Boutzios G, Tsavaris N, Kaltsas G: Current concepts in the diagnosis and management of poorly differentiated gastrointestinal neuroendocrine carcinomas. Endokrynol Pol 2013;64:60-72.

7 Fazio N, Spada F, Giovannini M: Chemotherapy in gastroenteropancreatic (GEP) neuroendocrine carcinomas (NEC): a critical view. Cancer Treat Rev 2013;39:270-274.

8 Raymond E, Dahan L, Raoul JL, Bang YJ, Borbath I, Lombard-Bohas C, Valle J, Metrakos P, Smith D, Vinik A, Chen JS, Hörsch D, Hammel P, Wiedenmann B, Van Cutsem E, Patyna S, Lu DR, Blanckmeister C, Chao R, Ruszniewski P: Sunitinib malate for the treatment of pancreatic neuroendocrine tumors. N Engl J Med 2011;364:501-513.
9 Yao JC, Shah MH, Ito T, Bohas CL, Wolin EM, Van Cutsem E, Hobday TJ, Okusaka T, Capdevila J, de Vries EG, Tomassetti P, Pavel ME, Hoosen S, Haas T, Lincy J, Lebwohl D, Öberg K: Everolimus for advanced pancreatic neuroendocrine tumors. N Engl J Med 2011; 364:514-523.

10 de Mestier L, Dromain C, d'Assignies G, Scoazec JY, Lassau N, Lebtahi R, Brixi H, Mitry E, Guimbaud R, Courbon F, d'Herbomez M, Cadiot G: Evaluating digestive neuroendocrine tumor progression and therapeutic responses in the era of targeted therapies: state of the art. Endocr Relat Cancer 2014; 21:R105-R120.

11 Öberg K, Akerström G, Rindi G, Jelic S: Neuroendocrine gastroenteropancreatic tumours: ESMO Clinical Practice Guidelines for diagnosis, treatment and follow-up. Ann Oncol 2010;21(suppl 5):v223-v227. 
12 Pavel M, Baudin E, Couvelard A, Krenning E, Öberg K, Steinmüller T, Anlauf M, Wiedenmann B, Salazar R: ENETS Consensus Guidelines for the management of patients with liver and other distant metastases from neuroendocrine neoplasms of foregut, midgut, hindgut, and unknown primary. Neuroendocrinology 2012;95:157-176.

13 Hadoux J, Favier J, Scoazec JY, Leboulleux S, Al Ghuzlan A, Caramella C, Déandreis D, Borget I, Loriot C, Chougnet C, Letouzé E, Young J, Amar L, Bertherat J, Libé R, Dumont F, Deschamps F, Schlumberger M, GimenezRoqueplo AP, Baudin E: SDHB mutations are associated with response to temozolomide in patients with metastatic pheochromocytoma or paraganglioma. Int J Cancer 2014;135: 2711-2720.

14 Raverot G, Sturm N, de Fraipont F, Muller M, Salenave S, Caron P, Chabre O, Chanson P, Cortet-Rudelli C, Assaker R, Dufour H, Gaillard S, François P, Jouanneau E, Passagia JG, Bernier M, Cornélius A, Figarella-Branger D, Trouillas J, Borson-Chazot F, Brue T: Temozolomide treatment in aggressive pituitary tumors and pituitary carcinomas: a French multicenter experience. J Clin Endocrinol Metab 2010;95:4592-4599.

15 Strosberg JR, Fine RL, Choi J, Nasir A, Coppola D, Chen DT, Helm J, Kvols L: First-line chemotherapy with capecitabine and temozolomide in patients with metastatic pancreatic endocrine carcinomas. Cancer 2011;117: 268-275.

16 Welin S, Sorbye H, Sebjornsen S, Knappskog S, Busch C, Öberg K: Clinical effect of temozolomide-based chemotherapy in poorly differentiated endocrine carcinoma after progression on first-line chemotherapy. Cancer 2011;117:4617-4622.

17 Kulke MH, Hornick JL, Frauenhoffer C, Hooshmand S, Ryan DP, Enzinger PC, Meyerhardt JA, Clark JW, Stuart K, Fuchs CS, Redston MS: $\mathrm{O}^{6}$-methylguanine DNA methyltransferase deficiency and response to temozolomide-based therapy in patients with neuroendocrine tumors. Clin Cancer Res 2009; 15:338-345.

18 Newlands ES, Stevens MF, Wedge SR, Wheelhouse RT, Brock C: Temozolomide: a review of its discovery, chemical properties, pre-clinical development and clinical trials. Cancer Treat Rev 1997;23:35-61.

19 Brock CS, Newlands ES, Wedge SR, Bower M, Evans H, Colquhoun I, Roddie M, Glaser M, Brampton MH, Rustin GJ: Phase I trial of temozolomide using an extended continuous oral schedule. Cancer Res 1998;58:43634367.

20 Newlands ES, Blackledge GR, Slack JA, Rustin GJ, Smith DB, Stuart NS, Quarterman CP, Hoffman R, Stevens MF, Brampton MH, et al: Phase I trial of temozolomide (CCRG 81045: M\&B 39831: NSC 362856). Br J Cancer 1992; 65:287-291.
21 Jen JF, Cutler DL, Pai SM, Batra VK, Affrime MB, Zambas DN, Heft S, Hajian G: Population pharmacokinetics of temozolomide in cancer patients. Pharm Res 2000;17:12841289.

22 Darkes JM, Plosker G, Jarvis B: Temozolomide: a review of its use in the treatment of malignant gliomas, malignant melanoma and other advanced cancers. Am J Cancer 2002;1: 55-80.

23 Wedge SR, Newlands ES: $\mathrm{O}^{6}$-benzylguanine enhances the sensitivity of a glioma xenograft with low $\mathrm{O}^{6}$-alkylguanine-DNA alkyltransferase activity to temozolomide and BCNU. Br J Cancer 1996;73:1049-1052.

24 Taverna P, Liu L, Hanson AJ, Monks A, Gerson SL: Characterization of MLH1 and MSH2 DNA mismatch repair proteins in cell lines of the NCI anticancer drug screen. Cancer Chemother Pharmacol 2000;46:507-516.

25 Boulton S, Pemberton LC, Porteous JK, Curtin NJ, Griffin RJ, Golding BT, Durkacz BW: Potentiation of temozolomide-induced cytotoxicity: a comparative study of the biological effects of poly(ADP-ribose) polymerase inhibitors. Br J Cancer 1995;72:849-856.

26 Ryu CH, Yoon WS, Park KY, Kim SM, Lim JY, Woo JS, Jeong CH, Hou Y, Jeun SS: Valproic acid downregulates the expression of MGMT and sensitizes temozolomide-resistant glioma cells. J Biomed Biotechnol 2012; 2012:987495.

27 Natarajan AT, Vermeulen S, Darroudi F, Valentine MB, Brent TP, Mitra S, Tano K: Chromosomal localization of human $\mathrm{O}^{6}$-methylguanine-DNA methyltransferase (MGMT) gene by in situ hybridization. Mutagenesis 1992;7:83-85.

28 Shiraishi A, Sakumi K, Sekiguchi M: Increased susceptibility to chemotherapeutic alkylating agents of mice deficient in DNA repair methyltransferase. Carcinogenesis 2000; 21:1879-1883.

29 Kaina B, Christmann M, Naumann S, Roos WP: MGMT: key node in the battle against genotoxicity, carcinogenicity and apoptosis induced by alkylating agents. DNA Repair (Amst) 2007;6:1079-1099.

30 Gilbert JA, Adhikari LJ, Lloyd RV, Halfdanarson TR, Muders MH, Ames MM: Molecular markers for novel therapeutic strategies in pancreatic endocrine tumors. Pancreas 2013; 42:411-421.

31 Chan AO, Kim SG, Bedeir A, Issa JP, Hamilton SR, Rashid A: CpG island methylation in carcinoid and pancreatic endocrine tumors. Oncogene 2003;22:924-934.

32 Arnold CN, Sosnowski A, Schmitt-Graff A, Arnold R, Blum HE: Analysis of molecular pathways in sporadic neuroendocrine tumors of the gastro-entero-pancreatic system. Int J Cancer 2007; 120:2157-2164.

33 Nakasu S, Fukami T, Baba K, Matsuda M: Immunohistochemical study for $\mathrm{O}^{6}$-methylguanine-DNA methyltransferase in the non-neoplastic and neoplastic components of gliomas. J Neurooncol 2004;70:333-340.
34 Ekeblad S, Sundin A, Janson ET, Welin S, Granberg D, Kindmark H, Dunder K, Kozlovacki $G$, Örlefors $H$, Sigurd $M$, Öberg K, Eriksson B, Skogseid B: Temozolomide as monotherapy is effective in treatment of advanced malignant neuroendocrine tumors. Clin Cancer Res 2007;13:2986-2991.

35 Preusser M, Janzer CR, Felsberg J, Reifenberger G, Hamou MF, Diserens AC, Stupp R, Gorlia T, Marosi C, Heinzl H, Hainfellner JA, Hegi M: Anti- $\mathrm{O}^{6}$-methylguanine-methyltransferase (MGMT) immunohistochemistry in glioblastoma multiforme: observer variability and lack of association with patient survival impede its use as clinical biomarker. Brain Pathol 2008; 18:520-532.

36 Hegi ME, Diserens AC, Gorlia T, Hamou MF, de Tribolet N, Weller M, Kros JM, Hainfellner JA, Mason W, Mariani L, Bromberg JE, Hau P, Mirimanoff RO, Cairncross JG, Janzer RC, Stupp R: MGMT gene silencing and benefit from temozolomide in glioblastoma. $\mathrm{N}$ Engl J Med 2005;352:997-1003.

37 Weller M, Tabatabai G, Kästner B, Felsberg J, Steinbach JP, Wick A, Schnell O, Hau P, Herrlinger U, Sabel MC, Wirsching HG, Ketter R, Bähr O, Platten M, Tonn JC, Schlegel U, Marosi C, Goldbrunner R, Stupp R, Homicsko K, Pichler J, Nikkhah G, Meixensberger J, Vajkoczy P, Kollias S, Hüsing J, Reifenberger G, Wick W: MGMT promoter methylation is a strong prognostic biomarker for benefit from dose-intensified temozolomide rechallenge in progressive glioblastoma: the DIRECTOR trial. Clin Cancer Res 2015;21:2057-2064.

38 Walter T, van Brakel B, Vercherat C, Hervieu V, Forestier J, Chayvialle JA, Molin Y, Lombard-Bohas C, Joly MO, Scoazec JY: $\mathrm{O}^{6}$-methylguanine-DNA methyltransferase status in neuroendocrine tumours: prognostic relevance and association with response to alkylating agents. Br J Cancer 2015;112:523-531.

39 Strosberg J, Cives M, Brelsford M, Black M, Meeker A, Ghayouri M: Identification of response predictors to temozolomide-based chemotherapy (H16 poster). 12th Annual Conference European Neuroendocrine Tumor Society, Barcelona, 2015.

40 Broder LE, Carter SK: Pancreatic islet cell carcinoma. II. Results of therapy with streptozotocin in 52 patients. Ann Intern Med 1973; 79:108-118.

41 Moertel CG, Lefkopoulo M, Lipsitz S, Hahn RG, Klaassen D: Streptozocin-doxorubicin, streptozocin-fluorouracil or chlorozotocin in the treatment of advanced islet-cell carcinoma. N Engl J Med 1992;326:519-523.

42 Kouvaraki MA, Ajani JA, Hoff P, Wolff R, Evans DB, Lozano R, Yao JC: Fluorouracil, doxorubicin, and streptozocin in the treatment of patients with locally advanced and metastatic pancreatic endocrine carcinomas. J Clin Oncol 2004;22:4762-4771. 
43 Turner NC, Strauss SJ, Sarker D, Gillmore R, Kirkwood A, Hackshaw A, Papadopoulou A, Bell J, Kayani I, Toumpanakis C, Grillo F, Mayer A, Hochhauser D, Begent RH, Caplin ME, Meyer T: Chemotherapy with 5-fluorouracil, cisplatin and streptozocin for neuroendocrine tumours. Br J Cancer 2010;102:11061112.

44 Ramanathan RK, Cnaan A, Hahn RG, Carbone PP, Haller DG: Phase II trial of dacarbazine (DTIC) in advanced pancreatic islet cell carcinoma. Study of the Eastern Cooperative Oncology Group-E6282. Ann Oncol 2001;12: 1139-1143.

45 Kulke MH, Stuart K, Enzinger PC, Ryan DP, Clark JW, Muzikansky A, Vincitore M, Michelini A, Fuchs CS: Phase II study of temozolomide and thalidomide in patients with metastatic neuroendocrine tumors. J Clin Oncol 2006;24:401-406.

46 Koumarianou A, Antoniou S, Kanakis G, Economopoulos N, Rontogianni D, Ntavatzikos A, Tsavaris N, Pectasides D, Dimitriadis G, Kaltsas G: Combination treatment with metronomic temozolomide, bevacizum$\mathrm{ab}$ and long-acting octreotide for malignant neuroendocrine tumours. Endocr Relat Cancer 2012;19:L1-L4.

47 Chan JA, Stuart K, Earle CC, Clark JW, Bhargava P, Miksad R, Blaszkowsky L, Enzinger PC, Meyerhardt JA, Zheng H, Fuchs CS, Kulke $\mathrm{MH}$ : Prospective study of bevacizumab plus temozolomide in patients with advanced neuroendocrine tumors. J Clin Oncol 2012; 30:2963-2968.

48 Tolcher AW, Gerson SL, Denis L, Geyer C, Hammond LA, Patnaik A, Goetz AD, Schwartz G, Edwards T, Reyderman L, Statkevich P, Cutler DL, Rowinsky EK: Marked inactivation of $\mathrm{O}^{6}$-alkylguanine-DNA alkyltransferase activity with protracted temozolomide schedules. Br J Cancer 2003;88:10041011.

49 Kerbel RS, Kamen BA: The anti-angiogenic basis of metronomic chemotherapy. Nat Rev Cancer 2004;4:423-436.

50 Olsen IH, Sørensen JB, Federspiel B, Kjaer A, Hansen CP, Knigge U, Langer SW: Temozolomide as second or third line treatment of patients with neuroendocrine carcinomas. ScientificWorldJournal 2012;2012:170496.

51 Chan JA, Blaszkowsky L, Stuart K, Zhu AX, Allen J, Wadlow R, Ryan DP, Meyerhardt J, Gonzalez M, Regan E, Zheng H, Kulke MH: A prospective, phase $1 / 2$ study of everolimus and temozolomide in patients with advanced pancreatic neuroendocrine tumor. Cancer 2013;119:3212-3218.

52 Fine R, Fogelman D, Schreibman S: Effective treatment of neuroendocrine tumors with capecitabine and temozolomide (abstract 4216). ASCO Gastrointestinal Cancers Symposium. J Clin Oncol 2005;23:16S.

53 Fine RL, Gulati AP, Krantz BA, Moss RA, Schreibman S, Tsushima DA, Mowatt KB, Dinnen RD, Mao Y, Stevens PD, Schrope B, Allendorf J, Lee JA, Sherman WH, Chabot JA:
Capecitabine and temozolomide (CAPTEM) for metastatic, well-differentiated neuroendocrine cancers: the Pancreas Center at Columbia University experience. Cancer Chemother Pharmacol 2013;71:663-670.

54 Murakami J, Lee YJ, Kokeguchi S, Tsujigiwa H, Asaumi J, Nagatsuka H, Fukui K, Kuroda $\mathrm{M}$, Tanaka N, Matsubara N: Depletion of $\mathrm{O}^{6}$ methylguanine-DNA methyltransferase by $\mathrm{O}^{6}$-benzylguanine enhances 5-FU cytotoxicity in colon and oral cancer cell lines. Oncol Rep 2007;17:1461-1467.

55 Spiro TP, Liu L, Majka S, Haaga J, Willson JK, Gerson SL: Temozolomide: the effect of onceand twice-a-day dosing on tumor tissue levels of the DNA repair protein $\mathrm{O}^{6}$-alkylguanineDNA-alkyltransferase. Clin Cancer Res 2001; 7:2309-2317.

56 Saif MW, Kaley K, Brennan M, Garcon MC, Rodriguez G, Rodriguez T: A retrospective study of capecitabine/temozolomide (CAPTEM) regimen in the treatment of metastatic pancreatic neuroendocrine tumors (pNETs) after failing previous therapy. JOP 2013;14:498-501.

57 Fine R, Gulati A, Tsushima D, Mowatt K, Oprescu A, Bruce J, Chabot J: Prospective phase II study of capecitabine and temozolomide (CAPTEM) for progressive, moderately, and well-differentiated metastatic neuroendocrine tumors. ASCO Gastrointestinal Cancers Symposium 2014. J Clin Oncol 2014; 32(suppl 3):abstract 179.

58 Spada F, Fumagalli C, Antonuzzo L, Messerini L, Radice D, Di Rocco R, Galdy S, Barucca V, Pisa E, Barberis M, Di Costanzo F, Fazio N: Capecitabine plus temozolomide (CAPTEM) in patients with advanced neuroendocrine neoplasms (NEN): an Italian multicenter retrospective analysis. ASCO Gastrointestinal Cancers Symposium 2014. J Clin Oncol 2014;32(suppl 3):abstract 281.

59 Peixoto R, Noonan R, Kennecke H, Lim H: Outcomes of patients treated with capecitabine and temozolamide (CAPTEM) for advanced pancreatic neuroendocrine tumors (pNETs) and non-pNETs. ASCO Gastrointestinal Cancers Symposium 2014. J Clin Oncol 2014; 32(suppl 3):abstract 343.

60 Claringbold PG, Price RA, Turner JH: Phase I-II study of radiopeptide ${ }^{177} \mathrm{Lu}$-octreotate in combination with capecitabine and temozolomide in advanced low-grade neuroendocrine tumors. Cancer Biother Radiopharm 2012;27:561-569.

61 Moertel CG, Kvols LK, O’Connell MJ, Rubin $\mathrm{J}$ : Treatment of neuroendocrine carcinomas with combined etoposide and cisplatin. Evidence of major therapeutic activity in the anaplastic variants of these neoplasms. Cancer 1991;68:227-232.

62 Sorbye H, Welin S, Langer SW, Vestermark LW, Holt N, Osterlund P, Dueland S, Hofsli E, Guren MG, Ohrling K, Birkemeyer E, Thiis-Evensen E, Biagini M, Gronbaek H, Soveri LM, Olsen IH, Federspiel B, Assmus J, Janson ET, Knigge U: Predictive and prognostic fac- tors for treatment and survival in 305 patients with advanced gastrointestinal neuroendocrine carcinoma (WHO G3): the NORDIC NEC study. Ann Oncol 2013;24:152-160.

63 Crona J, Fanola I, Lindholm DP, Antonodimitrakis P, Öberg K, Eriksson B, Granberg D: Effect of temozolomide in patients with metastatic bronchial carcinoids. Neuroendocrinology 2013;98:151-155.

64 Saranga-Perry V, Morse B, Centeno B, Kvols L, Strosberg J: Treatment of metastatic neuroendocrine tumors of the thymus with capecitabine and temozolomide: a case series. Neuroendocrinology 2013;97:318-321.

65 Crona J, Björklund P, Welin S, Kozlovacki G, Öberg K, Granberg D: Treatment, prognostic markers and survival in thymic neuroendocrine tumours. A study from a single tertiary referral centre. Lung Cancer 2013;79:289293.

66 Chong CR, Wirth LJ, Nishino M, Chen AB, Sholl LM, Kulke MH, McNamee CJ, Jänne PA, Johnson BE: Chemotherapy for locally advanced and metastatic pulmonary carcinoid tumors. Lung Cancer 2014;86:241-246.

67 Pietanza MC, Kadota K, Huberman K, Sima CS, Fiore JJ, Sumner DK, Travis WD, Heguy A, Ginsberg MS, Holodny AI, Chan TA, Rizvi NA, Azzoli CG, Riely GJ, Kris MG, Krug LM: Phase II trial of temozolomide in patients with relapsed sensitive or refractory small cell lung cancer, with assessment of methylguanineDNA methyltransferase as a potential biomarker. Clin Cancer Res 2012;18:1138-1145.

68 Zauderer MG, Drilon A, Kadota K, Huberman K, Sima CS, Bergagnini I, Sumner DK, Travis WD, Heguy A, Ginsberg MS, Holodny AI, Riely GJ, Kris MG, Krug LM, Pietanza MC: Trial of a 5-day dosing regimen of temozolomide in patients with relapsed small cell lung cancers with assessment of methylguanine-DNA methyltransferase. Lung Cancer 2014;86:237-240.

69 Chrisoulidou A, Kaltsas G, Ilias I, Grossman $\mathrm{AB}$ : The diagnosis and management of malignant phaeochromocytoma and paraganglioma. Endocr Relat Cancer 2007;14:569-585.

70 Kaltsas G, Rockall A, Papadogias D, Reznek $\mathrm{R}$, Grossman AB: Recent advances in radiological and radionuclide imaging and therapy of neuroendocrine tumours. Eur J Endocrinol 2004;151:15-27.

71 Bravo EL, Kalmadi SR, Gill I: Clinical utility of temozolomide in the treatment of malignant paraganglioma: a preliminary report. Horm Metab Res 2009;41:703-706.

72 Nozières C, Walter T, Joly MO, Giraud S, Scoazec JY, Borson-Chazot F, Simon C, Riou JP, Lombard-Bohas C: A SDHB malignant paraganglioma with dramatic response to temozolomide-capecitabine. Eur J Endocrinol 2012;166:1107-1111.

73 Payne MJ, Pratap SE, Middleton MR: Temozolomide in the treatment of solid tumours: current results and rationale for dosing/ scheduling. Crit Rev Oncol Hematol 2005;53: 241-252. 
74 Oberstein P, Gulati A, Krantz B, Moss R, Schreibman S, Tsushima D, Mowatt K, Allendorf J, Schrope B, Lee J, Sherman W, Chabot J, Fine R: The efficacy and safety of the capecitabine/temozolomide (CAPTEM) regimen in the treatment of well-differentiated neuroendocrine tumors with liver metastasis after failure of previous therapy: Columbia University Medical Center Experience. ASCO Gastrointestinal Cancers Symposium 2013. J Clin Oncol 2013;31(suppl 4):abstract 308.

75 Ganetsky A, Adel N, Do GK, Reidy D: The efficacy of capecitabine and temozolomide for the treatment of metastatic neuroendocrine tumors: Memorial Sloan-Kettering Cancer Center experience. ASCO Gastrointestinal Cancers Symposium 2012. J Clin Oncol 2012; 30(suppl 4):abstract 363.

76 Neyns B, Tosoni A, Hwu WJ, Reardon DA: Dose-dense temozolomide regimens: antitumor activity, toxicity, and immunomodulatory effects. Cancer 2010;116:2868-2877.

77 Su YB, Sohn S, Krown SE, Livingston PO, Wolchok JD, Quinn C, Williams L, Foster T, Sepkowitz KA, Chapman PB: Selective CD4+ lymphopenia in melanoma patients treated with temozolomide: a toxicity with therapeutic implications. J Clin Oncol 2004;22:610616.
78 Dresemann G: Temozolomide in malignant glioma. Onco Targets Ther 2010;3:139-146.

79 de Bono J, Denis L, Patnaik A, Hammond L, Geyer E, Gerson E, Cutler D, Reyderman I, Rowinsky E, Tolcher A: Extended temozolomine (TMZ) dosing schedules permit the administration of higher TMZ dose intensities and inhibit the DNA repair enzyme $\mathrm{O}^{6}$-alkylguanine DNA alkyltransferase (AGAT). Eur J Cancer 2001;37(suppl 6):S31-S32.

80 Neyns B, Chaskis C, Joosens E, Menten J, D'Hondt L, Branle F, Sadones J, Michotte A: A multicenter cohort study of dose-dense temozolomide ( 21 of 28 days) for the treatment of recurrent anaplastic astrocytoma or oligoastrocytoma. Cancer Invest 2008;26:269277.

81 Omuro A, Chan TA, Abrey LE, Khasraw M, Reiner AS, Kaley TJ, Deangelis LM, Lassman AB, Nolan CP, Gavrilovic IT, Hormigo A, Salvant C, Heguy A, Kaufman A, Huse JT, Panageas KS, Hottinger AF, Mellinghoff I: Phase II trial of continuous low-dose temozolomide for patients with recurrent malignant glioma. Neuro Oncol 2013;15:242-250.
82 Jalali R, Singh P, Menon H, Gujral S: Unexpected case of aplastic anemia in a patient with glioblastoma multiforme treated with temozolomide. J Neurooncol 2007;85:105-107.

83 Noronha V, Berliner N, Ballen KK, Lacy J, Kracher J, Baehring J, Henson JW: Treatment-related myelodysplasia/AML in a patient with a history of breast cancer and an oligodendroglioma treated with temozolomide: case study and review of the literature. Neuro Oncol 2006;8:280-283.

$84 \mathrm{Su}$ YW, Chang MC, Chiang MF, Hsieh RK: Treatment-related myelodysplastic syndrome after temozolomide for recurrent high-grade glioma. J Neurooncol 2005;71: 315-318.

85 Villano JL, Collins CA, Manasanch EE, Ramaprasad C, van Besien K: Aplastic anaemia in patient with glioblastoma multiforme treated with temozolomide. Lancet Oncol 2006;7:436-438.

86 Kesavan M, Claringbold PG, Turner JH: Hematological toxicity of combined Lu-octreotate radiopeptide chemotherapy of gastroenteropancreatic neuroendocrine tumors in long-term follow-up. Neuroendocrinology 2014;99:108-117. 